\title{
Efficient Utilization of Renewable Energy for Boilers in Tea café
}

\author{
Meenaakumari.M, Hema.R,John Paul Praveen.A.
}

\begin{abstract}
Due to continuous increase in emission of Greenhouse gases and the rapidly increasing fuel price, many countries in theis concerned with reduction of Liquefied Petroleum Gas (LPG) usage in teashops, which contains a mixture of Propane and Butane - both derived from distillation of crude oil. In terms of the by-products of their combustion, the gas released is $\mathrm{CO} 2$, which is considered as a greenhouse gas. This project mainly focus on reducing the utilization of LPG's as much as possible by using solar energy to preheat the water before entering the boiler at Tea shops and in addition auto-ignition setup has been added. Based on the temperature of the water inside the boiler, which is monitored continuously and fed to the microcontroller, the auto- ignition is turned on and gets off. Thus reducing LPG utilization in Tea shops. Added to that, in consideration with safety MQ6 for gas leakage detection, BMP180 for monitoring pressure and boiler water level detection are monitored and maintained. With all these it is able to minimize LPG utilization by $40 \%$ - 50\% during hot summer.

Keywords : Parabolic Trough Collector; Auto-Ignition; LPG Reduction; Pre-Heating.
\end{abstract}

\section{INTRODUCTION}

Resources in fields of agriculture, industries and domestic activities goes on increasing day by day. The main reason to switching to renewable resources is to reduce the emission of Greenhouse gases and to save money spent on purchasing hefty fuel. It is expected that solar energy utilization is going to be the emerging renewable technology in the near future. Here the main focus is on reducing the utilization of LPG's as much as possible by preheating the boiler water using solar energy. Using LPG to boil water is not ecofriendly and needs more maintenance. Zhang, G. et al. [3] energy collector and is an ecofriendly approach and here we use this model to minimize the utilization of LPG's by continuously monitoring water temperature in the boiler which has been preheated through solar energy and according to the temperature minimum or maximum auto-ignition is turned ON and OFF. Normally a busy tea café use 15 liters of water in a day for making 120 cups of tea and for boiling it they utilize around $2500 \mathrm{~g}$ of LPG per day. In Chennai licensed tea shop counts more than 15,000 and unlicensed one is not less in number. Approximately 2 Lakhs tea shops are there in major $10-15$

Revised Manuscript Received on July 22, 2019.

Meenaakumari.M Assistant Professor, Department of Electronics And Communication Engineering,, Bharath Institute of Higher Education and Research, Chennai, India meenumathi.m@gmail.com

Hema.R, Assistant Professor, Department of Electronics And Communication Engineering,, Bharath Institute of Higher Education and Research, Chennai, India . hemrbujradha@ gmail.com

John Paul Praveen.A, Assistant Professor, Department of Electronics And Communication Engineering,, Bharath Institute of Higher Education and Research, Chennai, India.johnpaul.embedded@gmail.com cities of Tamil Nadu. On an average in Tamil Nadu alone3to4LakhsTeashopsaretherewhereapproximately

Around $3,00,000 \mathrm{~kg}$ of LPG is used around Tamil Nadu alone. This could pollute the environment at high cost when it is considered all over the nation. Guven.H.M. et al. [10] proposed that the parabolic trough solar collectors are more suited for developing countries. Hence parabolic trough collector model will be more effective method in India to minimize the LPG utilization by pre heating the boiler water.

Since there is no ample awareness among the nation, even though Government comes forward to provide funds for installing solar energy, installation of solar energy is less in number. Government is concentrating on solar power generation and not on projects like this. If this project reach the people then LPG utilization in Tea shops is reduced by preheating the water before it reaches the boiler. Using this proposed project approximately $45 \%$ of regular LPG usage can be minimized throughout theyear.

\section{METHODOLOGY}

Among various types of solar collectors, in consideration with efficiency the Parabolic solar collector showed better results and this has been analyzed by Kalogirou, S.A. et al. [2]. Hence in the proposed method parabolic trough model to boil water in Tea shops isused.

Liang, H. et al. [5] has analyzed and proposed that parabolic trough model is cost effective compared to other solar collectors. Parabolic Trough is a type of solar concentrators that are curved as a parabola and Arasu, A.V. and Sornakumar, T. [6] has used new fiber reinforced plastics for the curved shape and is placed in a straight line, such that they concentrate solar radiation over a line focus. It tracks the sun in a single axis to transfer energy to water circulating through receiver pipe. The trough can thus said to be in its morning position at the start of the day. It moves to its noon position when the sun is directly overhead. By the end of the day, it moves to its evening position, following the sun all the way. This may be calculated continuously based on input to the Microcontroller from a solar radiation sensor that detects the sun's position. The other reason for using parabolic trough model is due to its compact size and this has been proposed by Fuqiang, W. et al. [4]. The motion to the parabolic trough may be electrical or hydraulic. In case of electrical, a servo or stepper is used. Bakos, G.C. [20] has proposed that the hydraulic system will used to track the position the troughs. The movement can be manualalso.

The water from the tank enters the collector pipe fixed above the parabolic trough where the parabolic trough reflects the heat into the iron collector pipe absorbed from the sunlight. The boiler water level is continuously monitored using LED's. When the water level in 
the boiler is minimum, which is measured using water level indicator and is indicated through LED. According to the level high, medium or low the inlet valve is opened and water is filled in theboiler.

The water which flows in the collector pipe gets heated up to $50^{\circ} \mathrm{C}$ and which can be noted using the temperature sensor (LM35). LM35 is a linear temperature sensor whose output voltage varies linearly with change in temperature. LM35 is three terminal linear temperature sensor. It can measure temperature from -55 degree Celsius to 110 degree Celsius. With the help of LM35 sensor in the boiler, the details about the temperature of water in the boiler is measured and it is displayed on 16x2 LCDmodule.

If the boiler temperature is less than $50^{\circ} \mathrm{C}$ auto ignition system starts and heated till necessary temperature is attained, which is monitored and displayed in the LCD display. This ignition is done using fixing the burner starter to the $10 \mathrm{rpm}$ dc motor and if the water inside the boiler has attained the necessary temperature for example 95 degree Celsius then the motor rotates anticlockwise direction, so that ignition gets turned off.

In case auto ignition fails to ignite the burner and gas leaking occurs then the gas sensor MQ6 fixed near the burner detect the leakage and buzzer gives alarm.

Due to high pressure, accidents may occur. By monitoring the pressure with the help of microcontroller and using automatic pressure releasing mechanism excess pressure is released. In addition Thermal Storage Tank can be used to store excess heat generated which can be utilized next day in the morning to reduce start up time period of the system.

\section{A.Parabolic trough collector}

The Parabolic trough collector is a solar energy collector designed to capture the sun light directly and more effectively than other types of solar collectors shown in figure1.1. The incoming sun light is reflected onto the collector pipe. So that water flows through the collector pipe gets heated. Beemkumar, N [14] has proposed different reflector material canbeused. Sagade A.A., [1] proposed that parabolic trough collector with mild steel receiver with glass cover shows more efficiency than without glasscover.

Aher, S. et al. [7] also analyzed and confirmed that glass covered receivers are more efficient setup. So that more heat can be focused on the collector pipe.

Gee, R.C. and Murphy, L.M. [8] has proposed that for higher operating temperature consideration of evacuated receiver tubes will be more effective.

Heat pipe receivers in place of evacuated can be used which is easily maintained which has been analyzed by Zhan.D et al. [12] and Liang, H [13].

De Oliveira Siqueira et al. [9] performed experimental analysis of solar parabolic trough concentratingsystem.

Forristall, R. [11] has experimentally proved that parabolic trough with any absorber and reflector material will not show much energy loss or gain, only slight changes will be there. Accordingly, the radiative forcing model suggested by [ 11 ] reveals that solar power is absorbed by specific coating on the $\mathrm{Qa}$, ab absorber and the $\mathrm{Qg}$, ab glass package. The power consumed by the specific layer is partially transported to the side wall of the absorber Qa, c, And then distributed to the working fluid by conduction of Qgain. Some of the energy absorbed by the absorber is transferred to the glass package by heat transfer Qc, a-g and Qr, a-g and lost through the ends of the receiver Q1, b. The energy absorbed by the envelope of glass and the energy used

From the inner wall to the outer wall of the glass container, convection Qc, g-e and radioactivity Qr, g-e[11 ] are lost to the atmosphere. The energy balance of the solar transmitter can be written as follows [11],

Qgain= Qa,c (1)

$\mathrm{Q} a, \mathrm{ab}=\mathrm{Qc}, \mathrm{a}-\mathrm{g}+\mathrm{Qr}, \mathrm{a}-\mathrm{g}+\mathrm{Q} \mathrm{a}, \mathrm{c}+\mathrm{Q} \mathrm{l}, \mathrm{b}(2) \quad \mathrm{Qg}, \mathrm{c}=$ Qc,a-g+Qr,a-g (3)

Qg,c +Qg,ab = Qc, g-e+Qr,g-e (4)

Therefore, any error in treating solar absorption as a surface phenomenon should be relatively small.

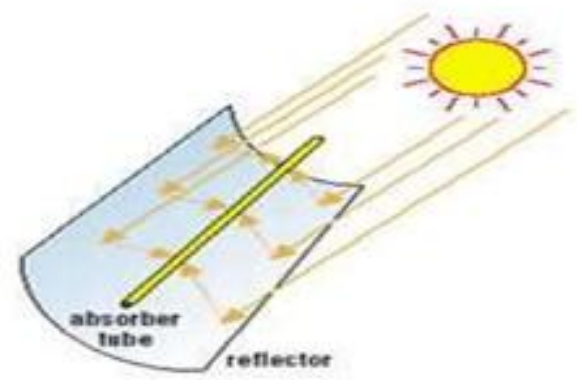

Fig 1Parabolic Trough Collector

\section{B.Temperature sensorLM35}

Wilcher, D. [18] proposed that LM35 can measure temperature more accurately and explained displaying temperature using LCD. Its measurement value ranges of $0^{\circ} \mathrm{C}$ to $+100^{\circ} \mathrm{C}$. This $\mathrm{LM} 35$ is used to measure the temperature of water inside the boiler at Tea café. It is monitored continuously and is displayed in LCD. Based on the water temperature auto-ignition getsstarted.

\section{C.10 rpm DCmotor}

$10 \mathrm{rpm} \mathrm{dc}$ motor works efficiently at $12 \mathrm{v}$ supply. Characteristics of DC motor has been analyzed by Liou, F.W. [16]. It is used for auto-ignition by fixing it to the ignition line of burner. When boiler water temperature is less the 50 degree Celsius it turns +90 degree. Since it is attached to the ignition system burner gets turned ON. In case if the boiler temperature is greater than 100 degree Celsius motor turns -90 degree. So that burner is turned OFF. This is controlled by PIC16f877amicrocontroller.

\section{D.Pressure sensorBMP180}

BMP180 is a high precision digital pressure sensor measuring pressure ranges from $300-1100 \mathrm{hpa}$ and its supply voltage is $1.8-3.6 \mathrm{~V}$. Monisha, D.S. [17] has represented it as digital friendly sensor. The measured data is stored in E2PRROM of BMP180 and it read via I2C of the pic microcontroller. The measured pressure value is displayed in LCD. This could help in avoiding accidents due to high pressure.

\section{E.Gas leakage detectorMQ6}

Apeh, S.T. [19] proposed MQ6 is high sensitive to LPG and has high response time. It is capable of detect gas leakage in less than 10 seconds. It is fixed near the burner at the same time it is placed in such a way

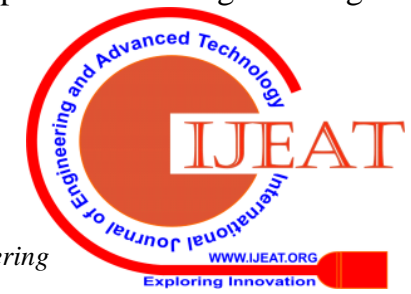


so that not affected by the flames. In case auto ignition fails to start and LPG starts leaking MQ6 detects the gas leakage and buzzer is interfaced to give indication.

\section{F. LevelDetection}

The boiler water level is monitored at three stages (high, medium, low). This is monitored by fixing copper bolts in the boiler at three points and connecting the wire in the other of the bolt shown in figure1.2. When water reaches the first level, it is indicated using LED through a wire connected in the other side of the boiler. To avoid salt deposition in the bolts it has to be removed and cleanedperiodically.

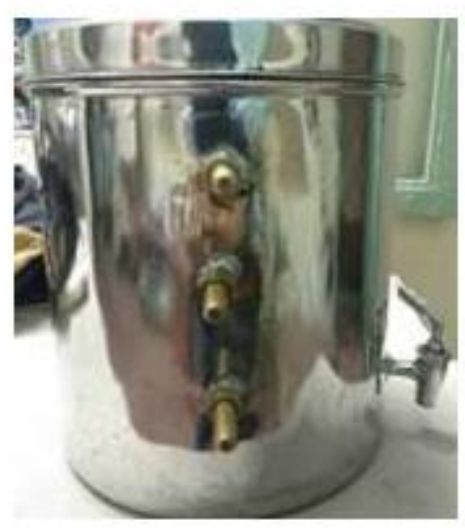

Fig.2 Water level detection using copper bolts

\section{III.BLOCKDIAGRAM:}

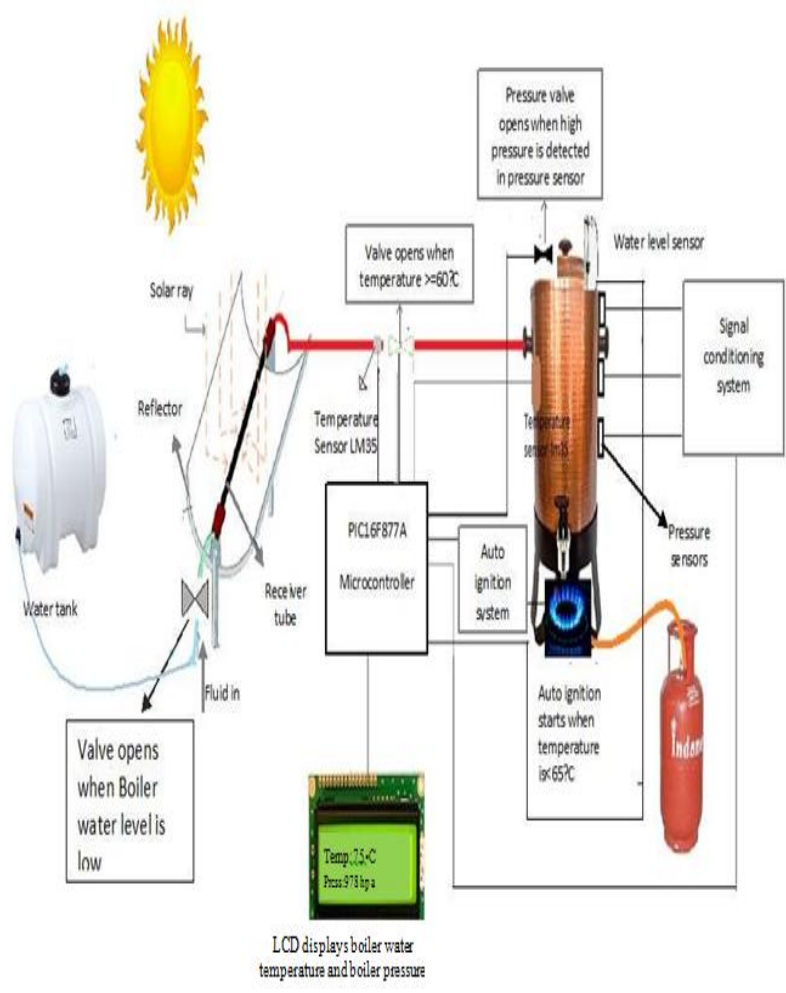

\begin{tabular}{|l|c|c|c|c|c|c|c|}
\hline Data & Date & $\begin{array}{l}\text { Atmospheric } \\
\text { Temperature } \\
\text { in }{ }^{\circ} \mathrm{C}\end{array}$ & $\begin{array}{l}\text { Water } \\
\text { Temperature } \\
\text { in }{ }^{\circ} \mathrm{C}\end{array}$ & $\begin{array}{l}\text { Water } \\
\text { Temperature } \\
\text { After } \\
\text { Preheating } \\
\text { incC } \mathrm{C}\end{array}$ & $\begin{array}{l}\text { Avg. Tea } \\
\text { Consumption } \\
\text { (no. of cups) }\end{array}$ & $\begin{array}{l}\text { LPG used } \\
\text { before } \\
\text { installing } \\
\text { preheating } \\
\text { setup ing }\end{array}$ & $\begin{array}{l}\text { LPG used } \\
\text { after } \\
\text { installing } \\
\text { preheaning } \\
\text { setup ing }\end{array}$ \\
\hline D1 & 29.09 .18 & 31 & 9 & 25 & 190 & 2090 & 1890 \\
\hline D2 & 02.10 .18 & 30 & 8 & 22 & 200 & 2200 & 2020 \\
\hline D3 & 04.10 .18 & 28 & 7 & 20 & 200 & 2200 & 2100 \\
\hline D4 & 11.12 .18 & 32 & 11 & 27 & 190 & 2090 & 1840 \\
\hline D5 & 17.12 .18 & 32 & 12 & 28 & 190 & 2090 & 1830 \\
\hline D6 & 02.01 .19 & 29 & 7 & 20 & 200 & 2200 & 2070 \\
\hline D7 & 03.01 .19 & 31 & 8 & 22 & 210 & 2310 & 2110 \\
\hline D8 & 05.01 .19 & 30 & 9 & 23 & 200 & 2200 & 2020 \\
\hline D9 & 06.01 .19 & 30 & 9 & 23 & 210 & 2310 & 2130 \\
\hline D10 & 07.01 .19 & 31 & 10 & 25 & 200 & 2200 & 2000 \\
\hline
\end{tabular}

Table 1 Observation table during winter

LPG utilization without and with preheating during winter

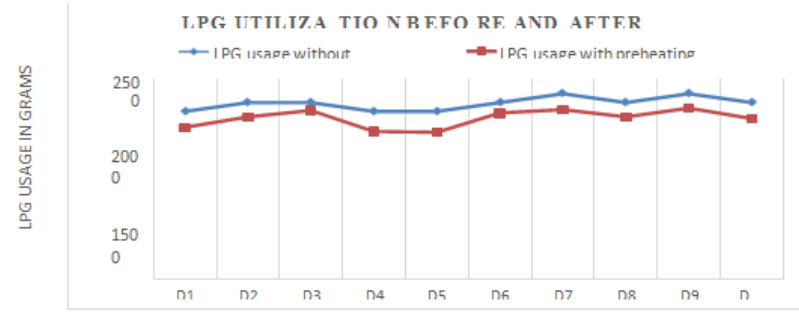

Fig.2LPG Utilization Without and With Preheating During Winter

FromtheTable4.1andFigure4.1itisseenthatduringwinterappro ximatelyitisabletoreduce15to20percentageof LPG in a busy Tea café by installing Pre heating system.

Table 2.Observation Table during summer

\begin{tabular}{|l|c|c|c|c|c|c|c|}
\hline Data & Date & $\begin{array}{l}\text { Atmospheric } \\
\text { Temperature } \\
\text { in }{ }^{\circ} \mathrm{C}\end{array}$ & $\begin{array}{l}\text { Water } \\
\text { Temperature } \\
\text { in }{ }^{\circ} \mathrm{C}\end{array}$ & $\begin{array}{l}\text { Water } \\
\text { Temperature } \\
\text { After } \\
\text { Preheating } \\
\text { in }{ }^{\circ} \mathrm{C}\end{array}$ & $\begin{array}{l}\text { Avg. Tea } \\
\text { Consumption } \\
\text { (no. of cups) }\end{array}$ & $\begin{array}{l}\text { LPG used } \\
\text { in grams } \\
\text { without } \\
\text { preheating } \\
\text { model }\end{array}$ & $\begin{array}{l}\text { LPG used } \\
\text { in grams } \\
\text { with } \\
\text { preheating } \\
\text { model }\end{array}$ \\
\hline D1 & 04.02 .19 & 33 & 12 & 30 & 210 & 2300 & 2010 \\
\hline D2 & 08.02 .19 & 35 & 15 & 36 & 200 & 2190 & 1820 \\
\hline D3 & 15.02 .19 & 34 & 14 & 36 & 200 & 2190 & 1830 \\
\hline D4 & 20.02 .19 & 34 & 13 & 35 & 190 & 2080 & 1720 \\
\hline D5 & 24.02 .19 & 37 & 16 & 40 & 190 & 2080 & 1690 \\
\hline D6 & 27.02 .19 & 35 & 14 & 37 & 200 & 2190 & 1820 \\
\hline D7 & 28.02 .19 & 36 & 15 & 40 & 200 & 2190 & 1790 \\
\hline D8 & 03.03 .19 & 36 & 16 & 42 & 210 & 2300 & 1900 \\
\hline D9 & 07.03 .19 & 39 & 17 & 49 & 170 & 1870 & 1120 \\
\hline D10 & 09.03 .19 & 37 & 16 & 47 & 180 & 1980 & 1450 \\
\hline
\end{tabular}

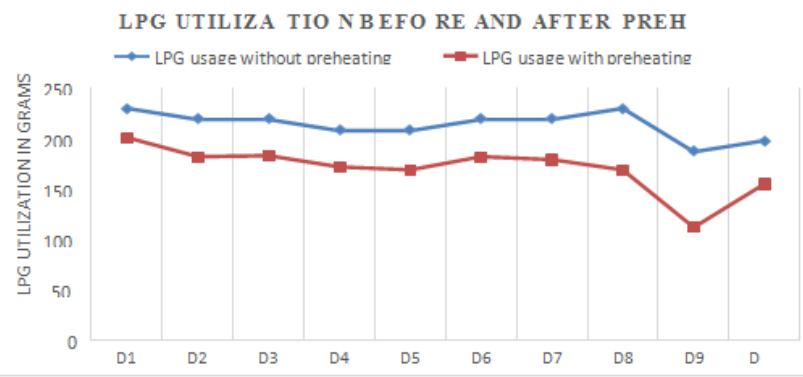

Fig.3LPG Utilization without and with Preheating During Summer

From the Table 4.2 and Figure 4.2 it is clear that, on an average during summer it is able to reduce 40 to $50 \%$ of LPG in a busy Tea café by installing Pre heating system. By increasing the size of the parabolic trough Collector pipe size it is able to achieve greater efficiency. 


\section{IV.CONCLUSION}

This development project is mainly used at Tea shops for preheating the water, before it enters the boiler and gets heated by LPG. Thus reducing the usage of LPG's at Tea shops. Parabolic trough collector setup had been used to preheat the boiler water. And further temperature sensor LM35 for monitoring the water temperature in the boiler continuously and displaying it in the LCD helps to know how much to be heated further by LPG, which minimizes LPG utilization. This ignition starts automatically when boiler water temperature is low. In case if auto ignition fails to open, MQ6 gas sensor detects the gas leakage and buzzer turns on. So that pollution caused by using LPG's at Tea shops is reduced. As this project implemented all over the nation then the usage of LPG's in large amount can be minimized. In addition to this, level sensors are used in to monitor the boiler water level and valve can opened only when the water level in the boiler is minimum. Since high pressure may leads to accidents, BMP180 is used to monitor the boiler pressure regularly.From the table 4.2 it is clear that on a hot sunny day it is able to reduce approximately $45 \%$ of LPG utilization. Hence by installing the pre heating system it is able to reduce $40 \%-50 \%$ of LPG during hot sunny day and it can be further increased by extending the size of parabolic trough collector and collector pipe.

\section{REFERENCES}

1. Kongkham, D. \& Sundararajan, M. 2019, "Distributed wideband sensing method for faded dynamic spectrum access", International Journal of Innovative Technology and Exploring Engineering, vol. 8, no. 10, pp. 4309-4312.

2. Balaji, S., John Paul Praveen, A. \& Mohanraj, R. 2019, "Recognizable proof and analysis of palm print in biometric authentication system using bayes techniques", International Journal of Innovative Technology and Exploring Engineering, vol. 8, no. 9 Special Issue 3, pp. 1126-1129.

3. Kavitha, G., Priya, N., Velvizhi, R. \& Allin Geo, A.V. 2019, "Parallel computation in correspondence and signal processing", International Journal of Innovative Technology and Exploring Engineering, vol. 8, no. 9 Special Issue 3, pp. 1136-1139.

4. Hema, R., Sundararajan, M. \& Balaji, S. 2019, "Smartphone control robot with automatic firing gun", International Journal of Innovative Technology and Exploring Engineering, vol. 8, no. 9 Special Issue 3, pp. 625-627.

5. Kaliyamurthie, K.P., Sundar Raj, B., Velvizhi, R. \& Shanmugapriya, K. 2019, "Dual band paper substrate CPW antenna for wireless applications", International Journal of Innovative Technology and Exploring Engineering, vol. 8, no. 9 Special Issue 3, pp. 605-608.

6. Geo, A.V.A., Arunachalam, A.R., Michael, G. \& Elankavi, R. 2019, "Evaluating architecture using compact modalities", International Journal of Innovative Technology and Exploring Engineering, vol. 8, no. 9 Special Issue 3, pp. 836-838.

7. Theivasigamani, S., Jeyapriya, D. \& Anita Davamani, K. 2019 "Anamoly analyzing and exploring for wireless sensor networks", International Journal of Innovative Technology and Exploring Engineering, vol. 8, no. 9 Special Issue 3, pp. 1116-1118.

8. Jeyapriya, D., Theivasigamani, S., Velvizhi, R. \& Nandhini, P. 2019, "Program detection in wireless feeler networks", International Journal of Innovative Technology and Exploring Engineering, vol. 8, no. 9 Special Issue 3, pp. 1194-1195.

9. Gowri Sankaran, B., Karthik, B. \& Vijayaragavan, S.P. 2019, "Image compression utilizing wavelet transform", International Journal of Innovative Technology and Exploring Engineering, vol. 8, no. 10, pp. 4305-4308.

10. Gowri Sankaran, B., Karthik, B. \& Vijayaragavan, S.P. 2019, "Weight ward change region plummeting change for square based image huffman coding", International Journal of Innovative Technology and Exploring Engineering, vol. 8, no. 10, pp. 4313-4316.

11. Hema, R., Sundararajan, M. \& Balaji, S. 2019, "Smartphone control robot with automatic firing gun", International Journal of Innovative
Technology and Exploring Engineering, vol. 8, no. 9 Special Issue 3, pp. 625-627.

12. Rangaswamy, K. \& Rajabhushanam, C. 2019, "Congestion control in wireless network using TCP friendly rate control (TFRC)", International Journal of Recent Technology and Engineering, vol. 8, no. 2 Special issue 3, pp. $1598-1602$.

13. Tamil Selvan, S. \& Sundararajan, M. 2019, "Performance Parameters of 3 Value 8t Cntfet Based Sram Cell Design Using H-Spice", International Journal of Recent Technology and Engineering, vol. 8, no. 2 Special issue 5, pp. 22-27.

14. Vinoth, V.V. \& Kanniga, E. 2019, "Steganographical techniques in hiding text images - system", International Journal of Recent Technology and Engineering, vol. 8, no. 2, pp. 6535-6537.

15. Saravana, S., Balaji, S., Arulselvi, S. \& John Paul Praveen, A. 2019, "Reliable power quality monitoring and protection system", International Journal of Innovative Technology and Exploring Engineering, vol. 8, no. 9 Special Issue 3, pp. 644-645.

16. Sundaramoorthy, A. \& John Wiselin, M.C. 2019, "Single patch antenna with multiple feed", International Journal of Innovative Technology and Exploring Engineering, vol. 8, no. 9, pp. 1743-1747.

17. Velavan, R., Bharanidharan, S. \& Sheeba, B. 2019, "EMF pollution Causes, effects and protection", International Journal of Innovative Technology and Exploring Engineering, vol. 8, no. 9 Special Issue 3, pp. 1166-1168.

18. Veer, R.A., Arulselvi, S. \& Karthik, B. 2019, "Construction of ensemble square classification approaches in MIMO OFDM", International Journal of Engineering and Advanced Technology, vol. 8, no. 5, pp. 2039-2041.

19. Agitha, W. \& Kaliyamurthie, K.P. 2019, "Improved energy efficient in WBAN using MAC with cloud computing", International Journal of Innovative Technology and Exploring Engineering, vol. 8, no. 8, pp. 2405-2408.

20. Kastro, G.G. \& Wiselin, M.C.J. 2019, "Design and analysis of stub loaded resonator", International Journal of Recent Technology and Engineering, vol. 8, no. 1 Special Issue4, pp. 272-283.

\section{AUTHORS PROFILE}

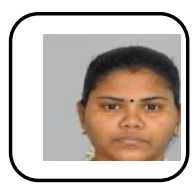

Meenaakumari.M Assistant Professor, Department of Electronics And Communication Engineering,, Bharath Institute of Higher Education and Research, Chennai,.

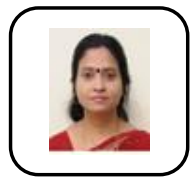

Hema.R, Assistant Professor, Department of Electronics And Communication Engineering, Bharath Institute of Higher Education and Research, Chennai, India.

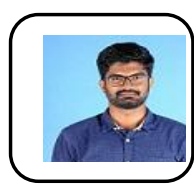

John Paul Praveen.A, Assistant Professor, Department of Electronics And Communication Engineering, Bharath Institute of Higher Education and Research, Chennai, India. 